\title{
Lengua y cultura: sobre las definiciones de canario 'baile antiguo originario de las Islas Canarias'
}

\author{
A Luis Cobiella
}

\section{Filología y Musicología}

La última edición del Diccionario académico (DRAE-92) tiene como 4. ${ }^{2}$ acepción de canario la de ser un 'baile antiguo originario de las Islas Canarias', y como 5. ${ }^{2}$ la de 'tañido correspondiente a ese baile'. El separar como acepciones distintas el 'baile' y 'su música' es práctica lexicográfica moderna, que se inicia en la ed. XIII del DRAE-1989, pero no la de considerar que hay dos aspectos - baile y música- en la definición de canario, pues ésta se remonta al primer diccionario académico, el Autoridades (1726).

Tiene razón la Academia al decir que es un baile antiguo, pues hoy no queda ni en Canarias ni fuera de las Islas baile alguno que reciba ese nombre. Otra cosa será que algunos rasgos del antiguo canario se hayan conservado en algunos bailes modernos ${ }^{1}$. Siguiendo a Lothar Siemens,

1 Para L. SIEmfns la única supervivencia del canario dentro de las islas es el sirinoque de La Palma (cf. "La música aborigen", Historia General de las Islas Canarias de A. Millares Torres. Las Palmas: Edirca, 1977, vol. I, p. 359). Para Elfidio Atonso, sin embargo, son tres los bailes actuales canarios que derivan del antiguo "canario: el sirinoque de La Palma, el baile del tambor de La Gomera y el tajaraste de Tenerife (cf. Estudios de folklore canario, Las Palmas: Edirca, 1985, p. 95). Y fuera de las Islas, son muchos los autores que señalan al zapateado, propio de varias regiones españolas y de algunos países hispanoamericanos, como descendiente del canario (cf. del propio E. Alonso, Estudios, p. 98, y Tierra Canaria, fasc. 1, Madrid, Zacosa, 1981). Pero aún hay más. Guiados más por la impresión y el deseo que por el conocimiento musical, algunos quisieron ver en el canario el origen de todo -o casi todoel folklore canario actual. Por ejemplo, para J. Br.thincotiRt AlFons) (Los cantos y danzas regionales, Santa Cruz de Tenerife, Librería Hespérides, s.a., p. 10) son derivaciones del canario, la guaracha, el tanganillo y las saltonas; y para I. MafFioTTF (que toma por fuente en esto a Lugo y MAssiev), el tango herreño, los corridos, el cirinoque (sic), el tajaraste $y$ otros bailes y guineos" (ibid., p. 29). Y hasta hubo quien (un escritor anónimo de "La Prensan de Buenos Aires) tuvo el canario como origen de la jota aragonesa (ibid., p. 46). En fin, que el canario se ha convertido incluso en recurso literario al que acuden escritores tan exquisitos como Dulce María Loynaz, quien al hacer el panorama de las fiestas, músicas y danzas que vio en su Un verano en Tenerife (2." ed., Viceconsejería de Cultura del Gobiemo de Canarias, 1992) no puede dejar de citarlo como antecedente de las actuales saltonas. Posiblemente guiada por la proximidad de los significantes, dice: Este rancio saltarelo canario debe ser el que hoy conocemos por saltona. (ibid., p. 383). Sin embargo, Luis Cobiella, que estudia las varias 
que es quien con mayor autoridad ha estudiado este tema ${ }^{2}$, entre los canarios aborígenes se practicaba -entre otras- una danza festiva de filas enfrentadas en las que los bailarines se acercaban y alejaban entre sí dando graciosos saltos. A lo que parece, la danza fue introducida en España por los muchos aborígenes que allí llegaron como esclavos (principalmente en los mercados de Sevilla y Valencia) ${ }^{3}$, "y allí fue adoptada -dice L. Siemens-, primero popularmente y luego en círculos cortesanos, para saltar luego de España a toda Europan, en un momento (el descubrimiento de América y la profusión de viajes a África) en el que - sigue nuestro autor- "lo exótico comenzó a interesar en el viejo continente de forma desmesurada ${ }^{4}$.

Tan rápida fue su difusión y tanta la fama que alcanzó, que no hay tratado de danza ni contexto literario de ambiente danzístico desde la mitad del siglo Xvi que no contenga el canario como uno de los bailes de moda. Así, en 1552, el cronista de Indias Francisco López de Gómara podrá decir que el nombre de las Islas Canarias atestigua su fama por el mundo gracias a los pájaros canarios y al baile canario.

manifestaciones que del Sirinoque quedaban por los pueblos de La Palma (*La música popular en la isla de La Palma", Revista de Historia. 80, 1947, pp. 454-484), renuncia a hablar de sus orígenes - implícitamente a relacionarlo con el canario aborigen-, pero concluye muy elocuentemente que "el ritmo del Sirinoque es universal carácter de la cosa rural, tanto en Canarias, como en África, como en Europan (el subrayado es del autor, p. 460).

2 Además de la publicación citada, en la que resume lo dicho anteriormente por otros autores, aportando la bibliografía al respecto, puede verse reproducido su artículo en su librito La música en Canarias (Las Palmas: El Museo Canario, 1977), pp. 15-29.

Entre la abundante bibliografia sobre la venta de esclavos canarios en la Península, véase el importante estudio de Vicenta Cokif́, "La conquista de las Islas Canarias a través de la venta de esclavos en Valencian, Anuario de Estudios Atlánticos, 1 (1955), pp. 479-544. En él se da cuenta de las impresiones de un viajero alemán, Jerónimo Münzer, que se encuentra a su paso con 65 tinerfeños que encadenados y con grillos eran obligados a trabajos durísimos, como serrar vigas y otros. (ibid., pp. 496-7). Mas, con todo, llama la atención del viajero alemán la "suave condición. de los isleños (cf. M. Alvak, "Adaptación, adopción y creación en el español de las Islas Canarias", Variedad y unidad del español, Madrid, Ed. Prensa Española, 1969. p. 173). La presencia de esclavos canarios en España en los tiempos de la conquista no pasó desapercibida, por esa condición y habilidades extraordinarias que mostraban tener. Una cita de Nebrija se ha hecho famosa sobre todas. "Yo vi en Sevilla una cosa que la califiqué por milagro. Estaba alli cierto isleño, natural de Canaria, el cual, sin mover el pie siniestro de un sitio, aguardaba ocho pasos de distancia a cuantos le querían arrojar piedras, cuyos golpes sabía evitar ya torciendo un poco la cabeza, ya apartando enteramente el cuerpo o ya mudando alternadamente las corvas. Este era un peligro a que se exponia tantas cuantas veces le ofrecían un cuarto" (Décadas, libro II, cap. I; cit. VIERA, Historia de Canarias, ed. A. Cioranescu, Santa Cruz de Tenerife, Ed. Goya, 1992, vol. I, p. 159).

- La música aborigen. p. 355. 


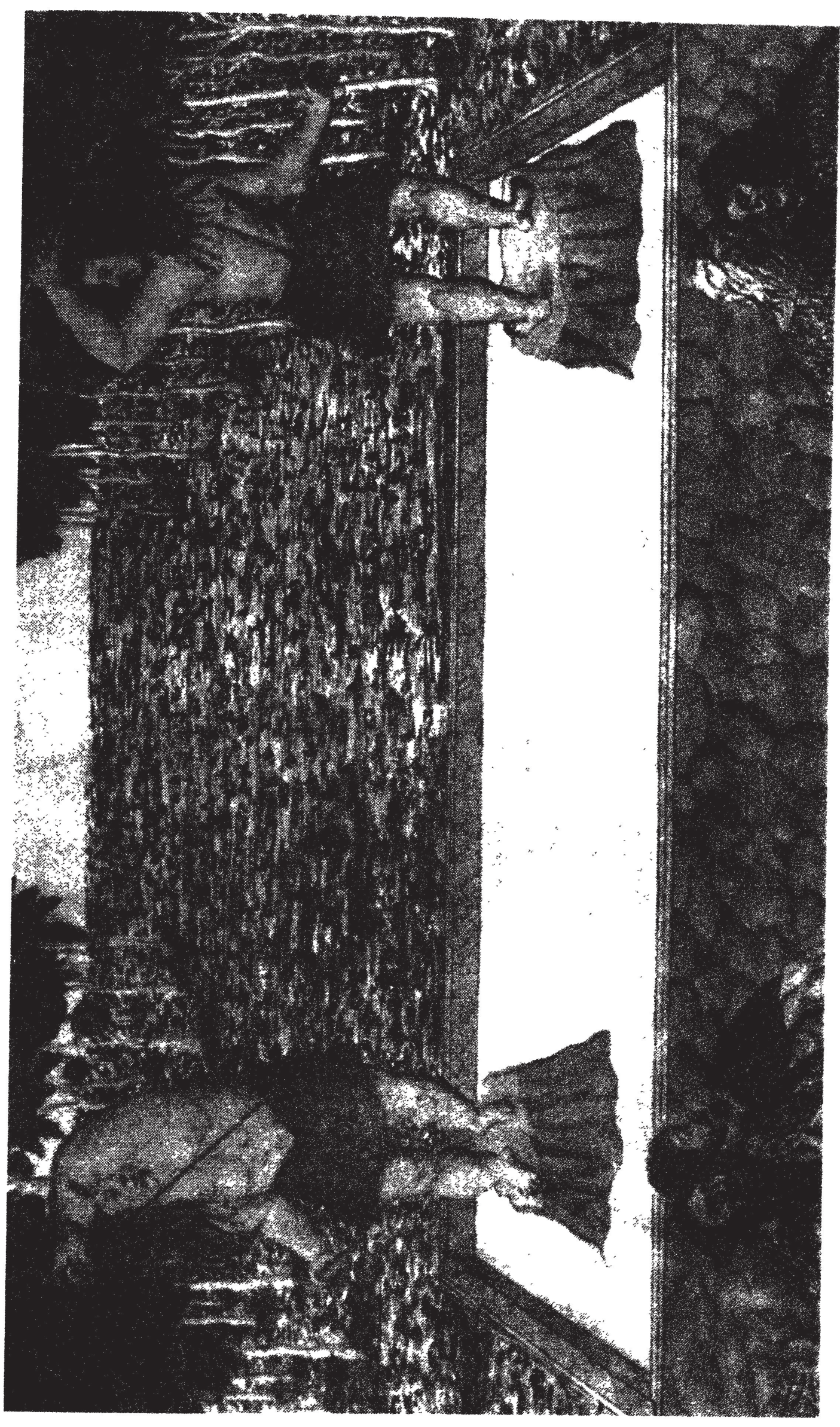

(c) Consejo Superior de Investigaciones Científicas 


\section{PREHISTORIA Y PROTOHISTORIA}

Pero cabe plantearse varias cuestiones al respecto. Porque parece lógico pensar que, en efecto, el baile fuera introducido en España por los esclavos canarios, pero es difícil decir en qué momento primero llegó a Sevilla o a Valencia, mercados principales a los que fueron llevados los esclavos canarios. La conquista de las Islas duró prácticamente todo el s. XV: se inició en Lanzarote y Fuerteventura en 1402 y finalizó en Tenerife en 1496; pero el tráfico de esclavos con los aborígenes canarios se había iniciado incluso antes de la Conquista, en el s. XIV con la arribada de italianos, portugueses y mallorquines ${ }^{5}$, y no finalizó hasta las primeras décadas del $s$. XVI. Además, no sabemos de qué isla procedía ese baile al que se bautizó canario, pues puede suponerse que no fuera común a todas las islas: si aún hoy hay notables diferencias de isla a isla entre los cantos y bailes más comunes del Archipiélago ${ }^{6}$, iqué no sería entre los aborígenes, incomunicados entre sí y de procedencia y antigüedad distinta! $\mathrm{Ni}$ hay por qué pensar que el llamado canario fuera el único baile de los aborígenes isleños ${ }^{7}$ y menos que aquél fuera el único del que deriven los actuales bailes de Canarias con raíces prehispánicas.

Un importante documento, dado a conocer muy recientemente ${ }^{8}$, nos asegura que ya en 1451, mucho antes de iniciarse la conquista de las islas principales (Gran Canaria, La Palma y Tenerife), era ya conocido el baile canario en Europa. El documento hace referencia a la boda de la infanta

"En Furopa - resume A. Viña Brito- se piensa en estos momentos en las posibilidades económicas de algunos de los productos canarios que eran bien conocidos, tales como los esclavos que se documentan en Portugal desde época de Alfonso IV (1325-57), en Mallorca desde mediados del siglo XIN y desde finales de esta misma centuria en Andalucía, tal como figura en la crónica de Enrique III en la que se señala que la expedición castellana de 1393 trajo cueros y cera, además de esclavos: ‘... e tomaron el rey e la reyna de la isla [de Lanzarote] con ciento e sesenta personas en un logar traxeron otros muchos de los moradores de la dicha isla..." (cit. A. Vina Brrto, "La conquista señorial", Historia de Canarias, Las Palmas de Gran Canaria, Ed. Prensa Ibérica, S.A., p. 120). Piénsese, además, que en la primera arribada a las islas de los normandos, en 1402, éstos traen consigo a dos aborígenes canarios, Alfonso e Isabel, para que les sirvan de alenguas" en la conquista; aborígenes que estaban en España ¿de que puerto los tomaron Bethencourt y Gadifer?-, lógicamente como producto de capturas de expediciones anteriores.

Y, además, cada isla posee sus propios y exclusivos géneros, como el baile del tambor en La Gomera, el sirinoque en la Palma, el tango y el vivo en El Hierro, etc.

L. SIFmfns resume la información de las Crónicas e Historias (sobre todo basándose en Abréu Galindo) diciendo que los canarios practicaban tres clases de danzas: una primera competitiva, esgrimiendo palos simulando lucha en la que mostrar las habilidades en atacar y escuivar, una segunda ritual, bailada en rueda" alrededor de algún símbolo, y una tercera festiva, bailada en folía", en filas enfrentadas y con cierto desorden, Cf. La música aborigen, pp. 35+-359.

" Leopoldo de la RosA, "Bailadores canarios en unas bodas reales europeas en 1451", Antuario de Estudios Atlänticos, 23 (1977). 
doña Leonor de Avis, hermana del rey de Portugal don Alfonso V, con el emperador de Alemania Federico III, celebrada en Lisboa el 13 de octubre de 1451. "Terminada la boda -dice el documento- hubo durante toda la noche bailes y juegos diversos..... Y sigue:

Después vinieron unos hombres salvajes, que viven en algún rincón del mundo, en unas islas lejanas del mar, pero bajo el señorío del señor rey de Portugal. diciendo haber sido enviados por sus jefes a estas bodas, e hicieron a su manera unos bailes muy particulares y dignos de admiración. Y es porque en aquella isla, que se llama Camaria [sic], había hombres desnudos de ambos sexos, la cual isla fue descubierta casualmente por el señor rey de Portugal, don Duarte [sic], etc. ?

Es muy pertinente el comentario del autor de esta importante noticia: "La mención a la intervención de los canarios - dice L. de la Rosa- es escueta y, a la verdad, el capellán de la emperatriz no podía estar peor informado sobre la fecha y circunstancias del descubrimiento y ocupación de nuestro archipiélago, que dice que lo habían sido "casualmente por el señor rey de Portugal don Duarte. ${ }^{10}$. Pero debemos añadir nosotros otros comentarios. "Vinieron unos hombres salvajes", dice el cronista, poniendo de manifiesto la extraña condición de aquellos isleños en una corte europea; "diciendo haber sido enviados por sus jefes a estas bodas", añade, desfigurando totalmente la realidad de aquellos isleños para enaltecer la de su rey y reina con la presencia de embajadas ade toda la cristiandad", pues es evidente que los canarios estaban allí no "venidos", sino llevados como cautivos fuera de su tierra; "e hicieron a su manera unos bailes muy particulares y dignos de admiración", termina; es decir, bailaron a su manera primitiva y "salvaje" un baile nunca visto antes y digno de toda admiración. Pero, atención, un baile tan admirable y tan particular que aún no tiene nombre; sólo es, todavía, el baile de unos hombres salvajes de unas islas lejanas que se llaman "Canaria", corregimos ya nosotros la evidente errata del escribano. ¿Y de qué isla? En teoría de cualquiera, pues aunque las tres mayores no estuvieran aún conquistadas, sí que habían sido asaltadas en busca de esclaỵos. L. de la Rosa argumenta que de la Gomera o de Lanzarote, puesto que en ese tiempo ulos portugueses detentaban el gobierno de la isla de Lanzarote, cedida por Maciot de Bethencourt y que mantenían relaciones amistosas con varios de los bandos en que se hallaba dividida la de La Gomera, por lo que lo más probable es que de una de estas dos islas procediesen aquellos "hombres salvajes" ${ }^{11}$.

Las referencias a los cantos y a los bailes de los canarios son abundantes en las Crónicas primitivas de la Conquista y en las Historias

\footnotetext{
$9 \quad$ Ibid., p. 663.

10 Ibid., p. 662.

$1 \quad$ Ibid., p. 662.
} 


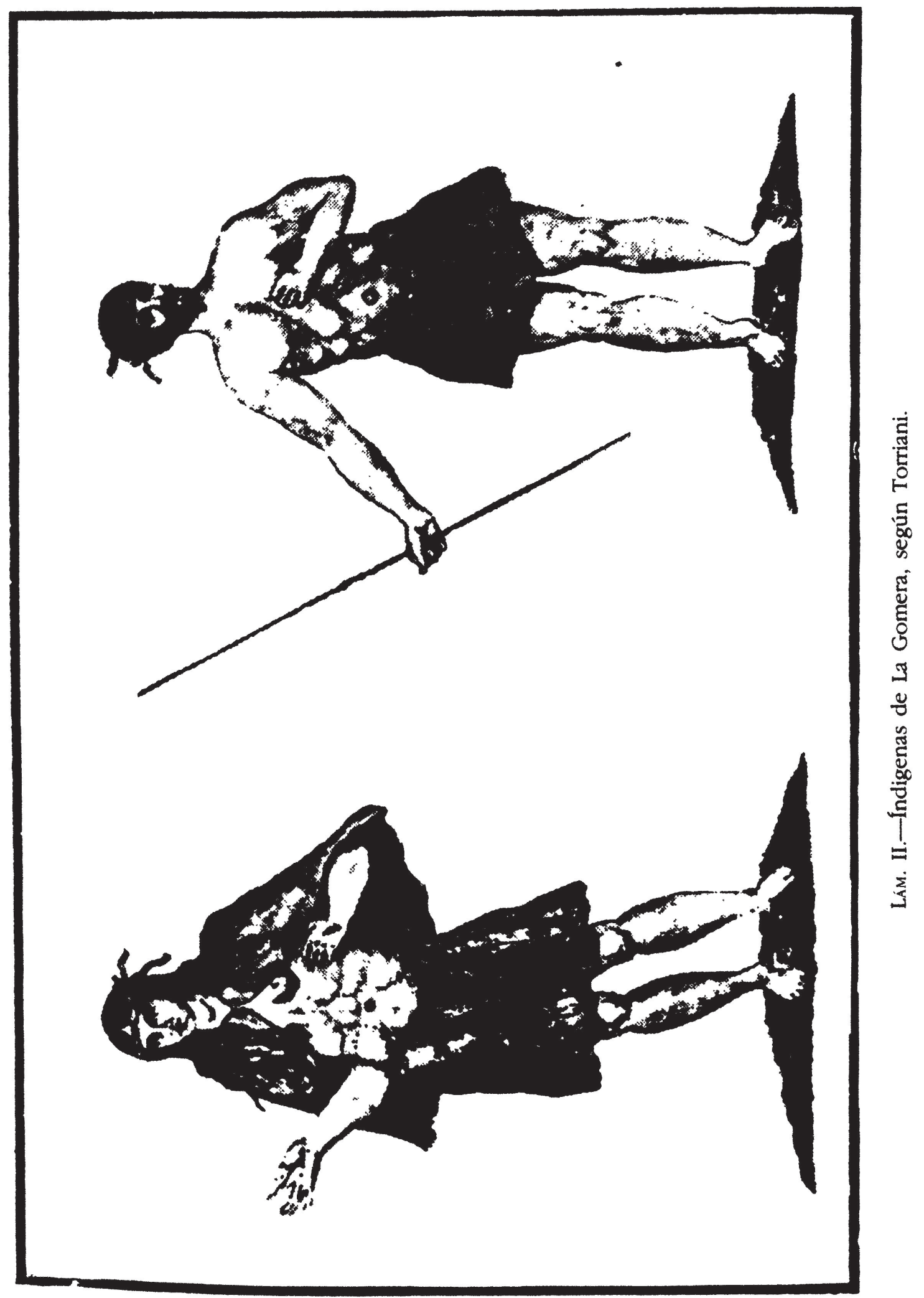


posteriores, pero deben tomarse con mucha cautela, pues las unas se copian a las otras, modificándose con variantes sucesivas que más parecen de propia invención que de observación directa o de referencia fidedigna por parte del historiador, como luego veremos. Todos ellos coinciden en señalar los rasgos de "tristeza, monotonía y melancolía" que caracterizaban las músicas de los aborígenes. Pero estos rasgos están especialmente atribuidos a las no menos famosas endechas de Canarias" ${ }^{12}$. Así que no debe confundirse el canario (baile muy rápido y vivo) con las endechas (canto de lamentación), como algunos han hecho, simplificando el panorama de los "géneros musicales" de los primitivos canarios ${ }^{13}$.

\section{PRIMERAS DOCUMENTACIONES}

Los primeros textos en los que se documenta la palabra canario, referida al baile, no son, obviamente, canarios ${ }^{14}$ : el nombre se le asigna fuera de las Islas. $\mathrm{Y}$ con ese nombre se identificó a un baile propio de

12 Cuyo nombre endecha aparece en la literatura de las Islas sólo a partir de las Historias de Canarias de finales del s. xvi, concretamente en las de Torriani y Abréu Galindo: .Cantaban versos de lamentación [...], y con tanta tristeza, que lloraban ellos mismos" (L. Torriani, Descripción de las Islas Canarias, ed. de A. Cioranescu, Goya Ed., Santa Cruz de Tenerife, 1978, p. 201); 'Cantaban a manera de endechas tristes en el tono y cortas. (Fr. J. de Arkér Gal.InDO, Historia de la Conquista de las siete Islas de Canaria, ed. de A. Cioranescu, Goya Ed., Santa Cruz de Tenerife, 1977, p. 87); "Sus cantares eran dolorosos y tristes, o amorosos, o funestos, a los cuales llamamos endechas" (Arkél: Gal Inıo, ibid., p. 157); además de otros testimonios posteriores.

13 Como hace, por ejemplo, E. Alonso al citar a Diego Pisador, vihuelista español del S. xvi, como documentación del canario, cuando PISADOr en su Libro de Música de Vibuela (Salamanca, 1552) sólo se refiere a las endechas (cf. E. Alonso, Estudios de folklore canario, cit., p. 115). Y como parece hacer también el muy benemérito investigador de la prehistoria isleña R. Verneat: en sus Cinco años de estancia en Canarias (ed. de José A. Delgado Luis, La Orotava, Tenerife, 1981), al recorrer a finales del s. xix las islas y describir los bailes de los herreños: -Estos bailes se ejecutaban habitualmente al son de una flauta de caña. Si ésta faltaba, se marcaba el compás con la boca y los pies, o mejor todavía, cantando. Los cantos, así como la música, estaban siempre impregnados de una gran melancolía y monotonía. (ibid., pp. 92-93). El máximo historiador de Canarias, Viera y Clavijo, por su parte, en 1772, junta ambos géneros -baile canario y endechas - al referirse a los naturales de la isla del Hierro: Acompañaban a este baile [el canario] con un aire de endechas lúgubres y patéticas, en las que trataban materias de amores y de infortunios que, traducidas a la lengua española, movian a lágrimas las personas de blando corazón. (J. VIera y Cl.Avjo, Historia de Canarias, ed. de A. Cioranescu, Santa Cruz de Tenerife, Goya Ed., 1982, 1, p. 157). Este testimonio de Viera lo hace suyo también el palmero B. Carballo Wangitemfrt en su libro de viaje por las islas occidentales las Afortunadas [1862] (Santa Cruz de Tenerife: Centro de la Cultura Popular Canaria, 1990), p. 178.

14 Decimos obviamente porque la lengua - y con ella las palabras- nace para hablar de lo ajeno, no de lo propio. 
los aborígenes; de tal manera que incluso cuando el nombre llega a las Islas conserva inequívoca la referencia a un "baile antiguo" propio y exclusivo de los canarios prehispánicos ${ }^{15}$. En esto la lengua no hizo sino cumplir su fin más elemental: el de dar nombre a algo para identificarlo como tal y diferenciarlo de lo demás.

Cuando el baile llega a la Península (y después a Europa) se le identifica en la lengua por su rasgo más característico, su procedencia de las Islas Canarias, y, por tanto, el canario. Pero, si el baile se llevó a la Península ${ }^{16}$ también quedó en las Islas ${ }^{17}$. Queremos decir que el baile no se extinguió en las Islas con la Conquista, pero que el nombre con el que ha entrado en la historia le vino de España. Es decir, que baile y nombre tuvieron historias diferentes y viajes cruzados: por una parte, el baile, que nació en las Islas y que se extendió por España y por Europa, "acortesanándose", derivando en formas diversas, alguna de las cuales volvió de nuevo a las Islas (mezclándose o no con el baile primitivo) hasta quedar fijado en alguno de los testimonios que hasta la actualidad parecen conservar la esencia del canario ${ }^{18}$; y, por otra, el nombre, que nació en España y que desde allí se difundió por todas partes, y que vino también a las Islas para referirse con exclusividad ${ }^{19}$ al baile que practicaban los aborígenes canarios.

Nuestro propósito aquí es estudiar el significado de canario 'baile' a partir de las definiciones lexicográficas de los diccionarios académicos y de otros diccionarios españoles. Para ello las muchas fichas lexicográficas de canario registradas en el Seminario de Lexicografía de la Real Academia Española ${ }^{20}$ han sido nuestra fuente documental principal. Pero hemos ampliado esas fuentes con los textos historiográficos más sobresalientes de Canarias y sobre Canarias, que la Academia ignora casi absolutamente, y que constituyen, a su vez, otra fuente fundamental. Además, hemos

15 Otra cosa será que el baile -o sus derivaciones, como dijimos- se conserve en alguna de las Islas o fuera de ellas.

16. Es decir, si alli fueron llevados algunos indígenas que lo bailaron y alli fueron imitados por otros -españoles y europeos- hasta convertirlo en danza muy estimada, primero en las plazas populares y después en las cortes (o al revés).

No hay por qué pensar que los traficantes de esclavos guanches pusieran como condición de su mercancía el que éstos supieran bailar el canario.

18 Lo que parece quedar claro, al decir de L. Siemens, es que el sirinoque palmero conserva la esencia del canario acortesanado y galante que se hizo famoso en España y en Europa, no el de los primitivos habitantes de las Islas (cf. La música aborigen, p. 359) que, al decir de otras fuentes, era un baile brioso, "pareciéndose en gran manera a la danza de los salvajes.

19 En las Islas con exclusividad, en España y en Europa sólo como referencia de origen.

24: Dejamos aquí constancia de nuestro agradecimiento muy sincero a Carmen Castillo Peña, becaria en su día de la Academia, que nos ayudó muchísimo en la localización de esas fichas. 


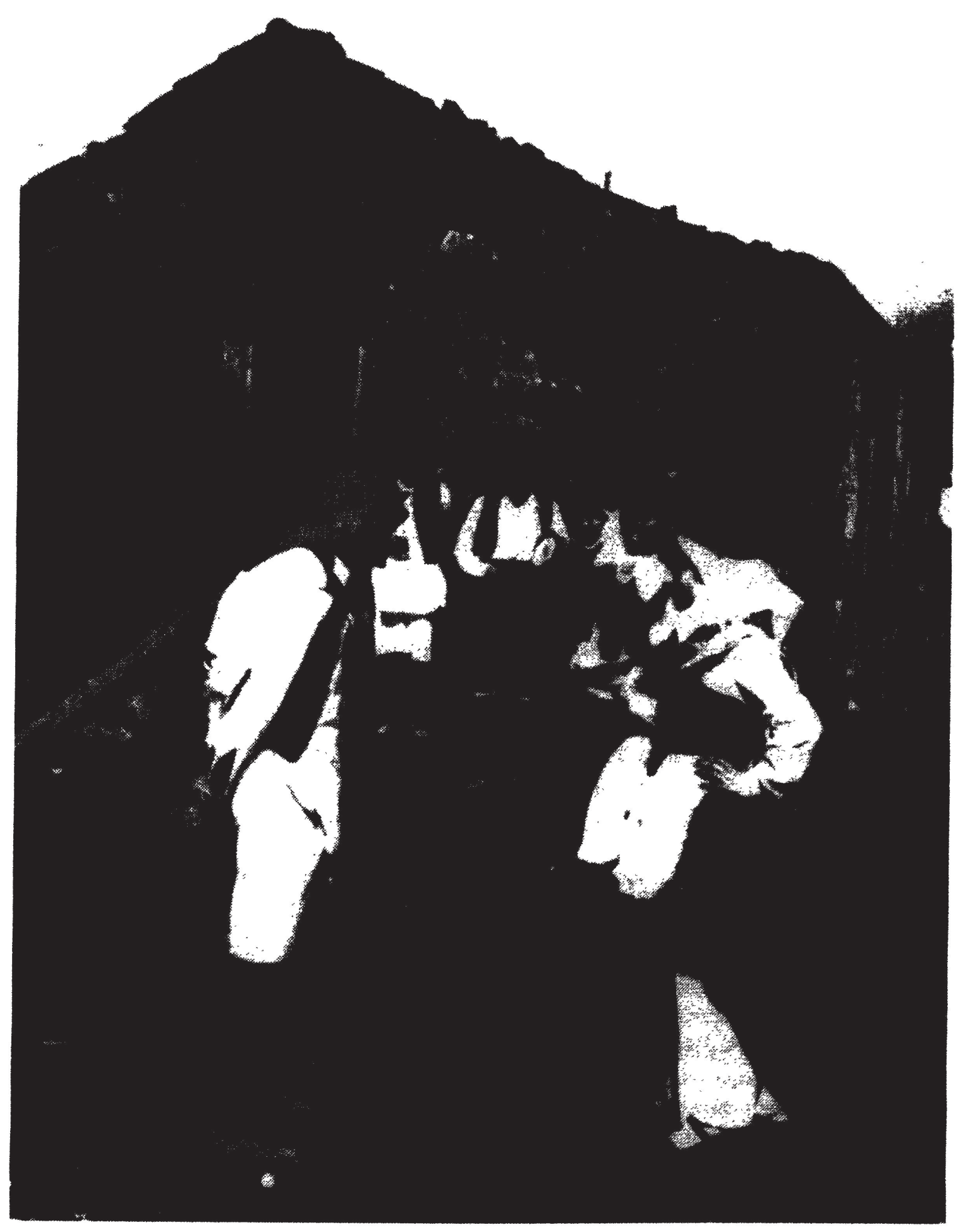

LÁm. III.-El sirinoque de La Palma parece ser la única danza actual de Canarias que tiene ciertas similitudes con el antiguo canario. (En la foto el Grupo de las Tricias bailando el sirinoque). 
revisado la brevísima bibliografía existente sobre la palabra canario y sobre el baile canario ${ }^{21}$.

En todos los casos hemos acabado revisando directamente las fuentes y los textos citados, no ya tanto por confirmar su veracidad (cosa que damos por descontada en los procedentes de la Academia) como por ampliar el contexto en que las distintas citas se producen y poder entender así mejor su verdadero sentido.

No se trata, pues, de un estudio etnográfico con el propósito de "restaurar" la forma de ejecución del baile primitivo, ni de rastrear las distintas derivaciones que el baile ha tenido en España y en el mundo, ni siquiera las supervivencias que pueden atribuírsele en Canarias. Tampoco de un estudio técnico desde el punto de vista de la historia de las danzas populares españolas. De alguno de esos aspectos necesariamente nos tendremos que ocupar en el elemental comentario de los textos correspondientes. Nuestro estudio tiene un carácter lingüístico -lexicológico y lexicográfico-, tomando como base los muchos y muy heterogéneos textos en los que se contiene la palabra canario, especificada en la definición del DRAE como baile antiguo originario de las I.C.'.

Precisamente la heterogeneidad de los textos aconseja agruparlos en cuatro tipos de fuentes para su estudio. Éstas son:

a) Historiográficas: Sobre la historia de Canarias, especialmente en los capítulos dedicados a los usos, costumbres y formas de vida de los aborígenes isleños. Como no podía ser de otra forma, la gran mayoría de esos textos son de autores canarios o de autores que sin serlo escribieron desde Canarias. Y una gran mayoría de ellos contienen también consideraciones y observaciones sobre el baile o sobre su nombre, que les hacen ser no sólo meros registros léxicos sino fuentes valorativas.

b) Literarias: Textos sin temática específica concreta, caracterizados todos por su finalidad meramente literaria, en la que la palabra canario aparece sin otra referencia especial añadida que la de 'baile'. Son citas testimoniales de su existencia.

\footnotetext{
2 Sobre el baile ya hemos citado los trabajos de L. Siemens y E. Alonso, que por ser los más recientes, resumen y aportan la bibliografia anterior. Y sobre la palabra canario, puede verse el artículo de J. Rfirito Pérfz, "Historia y geografía de la palabra canario. III Coloquio de Historia Canario-Americana (Las Palmas: Cabildo Insular de Gran Canaria, 1978), vol. I, pp. 523-529, aunque advertimos que en él se ocultan todas las fuentes de donde se toman los datos y citas. De cierto ocultamiento bibliográfico (aunque en menor medida que Régulo) pecan también los artículos de E. Alonso al citar textos y autores. Sobre todo esto y sobre las distintas acepciones de canario en el Diccionario académico ( $y$ otros) nos hemos ocupado nosotros en un extenso artículo: "Variantes e invariantes de contenido en las definiciones del Diccionario académico: sobre el (los) significado(s) de canario, Boletín de la Real Academia Española, LXXI. CCCLIII (mayo-agosto 1991), pp. 245-273.
} 
c) Técnicas: Procedentes, sobre todo, de Tratados y Libros de Danzas, desde donde se cita y examina el canario en su pura realidad, con una intencionalidad descriptiva.

d) Lexicográficas: Desde el Tesoro de Covarrubias (1611) ${ }^{22}$ hasta el DRAE-92, pasando por todas las ed. del Diccionario académico, desde el Autoridades (1726), y por los otros diccionarios no académicos más importantes del español. Naturalmente estos textos pretenden no sólo documentar la palabra sino definirla.

\section{FUENTES HISTORIOGRÁFICAS Y CRONISTICAS}

\section{Las crónicas}

El caso es que para encontrar la primera documentación del baile canario en textos historiográficos nacidos en las Islas hay que esperar hasta finales del siglo XVI. Ni aparece en Le Canarien (crónicas francesas de la conquista betancuriana de Canarias ${ }^{23}$ ), ni aparece tampoco en las primitivas Crónicas castellanas de la Conquista: las denominadas Ovetense, Matritense y Lacunense, además de las Historias de López de Ulloa, de Antonio Sedeño y de Gómez Escudero ${ }^{2+}$. Pero aunque, en efecto, nunca se cita la palabra canario, en las de redacción más tardía (las de Sedeño y Gómez Escudero, ya del siglo Xvil) se menciona un tipo de baile que los aborígenes isleños ejecutaban en los casamientos y para el que se requería un especial adiestramiento por los "zapateados, mudanzas y cabriolas" que tenía, que bien podría ser el canario ${ }^{25}$.

22 Esta acepción no se recoge todavía ni en el Vocabulario Universal de A. de PAlfNicia (1490) ni en los dos de Nebrija, Dictionarium latino-bispánicum (1492) y Dictionarium bispano-latinum (1495).

2 La primera, la de Gadifer de la Salle, escrita a raíz de la Conquista, posiblemente entre 1404 y 1407, y la segunda, la de Juan de Bethencourt, escrita posiblemente entre 1488 y 1491. Cf. Le Canarien (Crónicas francesas de la Conquista de Canarias), ed. de A. Cioranescu (Cabildo Insular de Tenerife, 3. ed., 1986).

24 Redactadas éstas a lo largo de los siglos xvi y xuI, como "versiones" tardías de una original y perdida Crónica de la Conquista de Canarias, atribuida al Alférez Mayor de la Conquista de Canaria, Alonso Jáimez de Sotomayor, escrita a raíz de los hechos descritos, por lo tanto a finales del xv o principios del xu. Cf. F. Moralfs Paldrón, Canarias. Crónicas de su Conquista (Las Palmas: Ayuntamiento de Las Palmas de Gran Canaria y El Museo Canario, 1978), especialmente las pp. 11-13.

25 Ibid., pp. 366 y 433-439. Sobre esta enrevesada historia de citas y recitas de los primeros cronistas, véase el documentado estudio de M. R. Alonso, "Las danzas y canciones populares de Canarias", El Museo Canario, 25-26 (1948), especialmente las pp. 85-88. 


\section{López de Gómara}

La primera fuente historiográfica que cita expresamente el baile canario es la del cronista de Indias Francisco López de Gómara, quien en su Historia General de las Indias [1552] ${ }^{26}$ introduce un breve e interesantísimo capítulo dedicado a la "Conquista de las islas de Canaria" (muy poco citado, por otra parte, en la historiografía de las Islas ${ }^{27}$ ), al final del cual dice: "Dos cosas andan por el mundo que ennoblecen estas Islas: los pájaros canarios, tan estimados por su canto, que no hay en otra ninguna parte, a cuanto afirman, y el canario, baile gentil y artificioso" ${ }^{28}$.

Y dos cosas cabe destacar respecto al canario baile de esta cita de Gómara: la primera, que ya a mitad del s. XVI el baile era famoso y se bailaba por todo "el mundon; y la segunda, que la calificación que el cronista le da de "gentil y artificioso" significa que ya el baile había evolucionado de su naturaleza primera (espontáneo, brioso, como salvaje, de "violentos y cortos movimientos" - que dirán de él-) a unas formas galantes y "hechas con arte" (como define Covarrubias lo de "artificioso") ${ }^{29}$.

\section{Méndez Nieto}

En una fecha relativamente temprana en comparación a las de los historiadores, en 1561, un médico portugués, nacido en Miranda do Douro, el licenciado Méndez Nieto, autor de unos famosos Discursos

26 (Ed. de Ribadeneyra, B.A.E., Madrid, 1852).

:- Lo mismo que la de su contemporáneo y también historiador de Indias, Fr. Bartolomé de las Casas, quien h. 1556 escribió una Brevisima Relación de la destrucción de Africa, preludio de la destrucción de Indias. Primera defensa de los guancbes y negros contra su esclavización (ed. de I. Pérez Fernández, Salamanca: Viceconsejería de Cultura y Deportes del Gobiemo de Canarias y Ed. San Esteban, 1989), en la que, como en la segunda parte del título se indica, además de ofrecer alegatos furibundos contra los conquistadores castellanos y normandos que vinieron a quebrar la paz de una raza y de un pueblo -el guanche-, que estaba en sus tierras seguro y pacífico, sin a nadie "molestar, ni hacer injuria, violencia ni daño alguno a viviente persona del mundo* ( $i b i d .$, p. 219), nos muestra un panorama histórico de los primeros tiempos de la Conquista y de las condiciones, costumbres y religión de la gente natural de las islas de Canaria. (caps. I al V). La obra del P. Las Casas en relación con Canarias es aún menos conocida que la de López de Gómara, pero no menos interesante. En relación a nuestro baile canario nada dice el dominico, sólo que los habitantes de La Gomera extendian todo su tiempo en cantar y bailar y en el uso de las mujeres, y esto tenían por su bienaventuranza. (p. 231).

28 Historia General de las Indias. 1, cap. 224, p. 294.

29) Esto es lo que cabe entender del "gentil y artificioso* de Gómara, en aplicación del sentido concorde que contrae en otros textos contemporáneos y en los diccionarios de la época. 
Medicinales, como fruto de su estancia en la isla de La Palma ${ }^{30}$, describe el ambiente refinado en el que se vivía en aquella isla ("este microcosmos surgido del mundo español en expansión posee refinamientos que recuerdan la cortem, dice $)^{31}$, y asiste a unna sesión de baile muy canario [...] con el canario como colofón. ${ }^{32}$.

Si ya en estas fechas (1561) la palabra canario está en las Islas como denominación específica de un tipo de baile, es para sustituir a la denominación de sirinoque que, con toda probabilidad, designaba al mismo baile. Curioso trueque: pues siendo el baile canario de origen, recibe el nombre de canario de los que vienen de afuera (de España y de Europa), mientras que se silencia el nombre que previsiblemente tenía dentro de la isla, el de sirinoque, nombre que, por otra parte, es el que ha pervivido popularmente en aquella isla hasta hoy.

\section{Espinosa, Torriani y Abréu}

Después del testimonio de López de Gómara, tres son las documentaciones de la palabra canario en la historiografía de las Islas en el siglo XVI, las tres de la última década del siglo, por obra de sus tres principales historiadores: Torriani, Espinosa y Abréu Galindo. Y las tres aparecen en contextos muy similares: en los capítulos en que se describen las formas de vida y las costumbres de los aborígenes.

La del ingeniero italiano Leonardo Torriani (1590) con referencia a los habitantes del Hierro dice: "Bailaban cantando, porque no tenían otro instrumento; y creo que de allí tiene su origen el famoso baile canarion ${ }^{33}$.

La del dominico Fr. Alonso de Espinosa (1594), aunque no se diga expresamente, y a juzgar por el título y temática de su obra, con referencia a los habitantes de Tenerife: "Y aquí mostraba cada cual su valor, haciendo alarde de sus gracias en saltar, correr, bailar aquel son que llaman canario, con mucha ligereza y mudanzas" ${ }^{34}$.

Y la del franciscano Fr. Abréu Galindo (h. 1596) ${ }^{35}$, referido a los habitantes de Gran Canaria: "Tenían casas donde se juntaban a bailar y

30 Marcel Batalllon, La isla de La Palma en 1561: Estampas canarias de Juan Méndez Nieto (La Laguna: Instituto de Estudios Canarios, 1987).

i Ibid., p. 19.

32 Ibid., p. 20.

33 Descripción de las Islas Canarias, ed. de A. Cioranescu (Santa Cruz de Tenerife: Goya Ed., 1978), pp. 212-213.

34 Historia de Nuestra Señora de Candelaria, ed. de A. Cioranescu (Santa Cruz de Tenerife: Goya Ed., 1967), p. 38.

35 Aunque la obra de Abréu Galindo se publicó por vez primera en 1632, su redacción parece anterior a 1600 . Cf. Fr. J. de ABré, Galindo, Historia de la Conquista de las siete Islas de 
cantar. Su baile era menudico y agudo, el mismo que hoy llaman canarion ${ }^{36}$.

Las tres citas son ya muy tardías, entre 150 y 200 años posteriores al inicio de la Conquista de las Islas, y desaparecidos ya los guanches como raza y como pueblo. Así que poco o nada nos aclaran respecto a la pervivencia del baile en la época en la que ellos escriben. Más parece que, además de historia, es historia pasada, llegada a ellos por referencias y testimonios ajenos. Porque la cita de Abréu Galindo no es más que una derivación amplificada de lo que las Crónicas primitivas decían de las diversiones de los aborígenes, y lo que hace el franciscano no es sino ponerle el nombre de canario ("que boy llaman canario", dice) a los bailes que en las Crónicas no tenían ninguno ${ }^{37}$. Porque ¿quiénes eran los que llamaban canario a ese baile? Desde luego que no los propios indígenas (a pesar del texto de Espinosa), sino los contemporáneos de los historiadores, sean los propios habitantes de las Islas, sean los de fuera de ellas, en donde el baile ha tomado fama ("el famoso baile canario", dice Torriani).

\section{Núñez de la Peña}

La siguiente cita del canario baile es de la segunda mitad del s. Xvil (1676) y pertenece al historiador tinerfeño Juan Núñez de la Peña, quien describe los juegos y danzas de los canarios de Tenerife de la forma siguiente:

Todos los años en los postrimeros días del cuarto mes que es Abril, celebraban fiestas anales, por espacio de nueve días; juntábanse los de cada Reyno en el Palacio de su Rey: allí se regocijaban con juegos, danzas, bailes, cada uno mostraba su habilidad cual en hacer pruebas cual en correr y saltar, otros en danzar el canario, que lo bailaban con destreza y diversas mudanzas ${ }^{18}$.

La Historia de Núñez de la Peña, aparte su visión "romántica" de la realidad de los primitivos canarios, debe mucho a las de Abréu y Espi-

Canaria, ed. de A. Cioranescu (Santa Cruz de Tenerife, 1977), sobre todo las pp. IX-XIII de la Introducción.

4. Ibid., p. 157.

(1) Dice la Crónica Otetense, a la que indudablemente toma como fuente el franciscano: "[Tenían los canarios] casas de rrecreación y pasatiempos, donde se juntaban onbres y mujeres a cantar y a bailar, y acabados sus cantos y bailes, ordenaban sus banquetes y comidas de mucha carne asada y cosida (cf. F. MORAl es Palnon, Canarias. Crónicas de su Conquista, cit., p. 162).

3N Juan Nivfz bF iA PFva. Conquista y Antigüedades de las Islas de la Gran Canaria y su descripción [Madrid, 1676] (Reimpresa en Santa Cruz de Tenerife: Imprenta La Isleña, 1847), pp. 31-32. 
nosa, pero en este punto la descripción del canario coincide con la del segundo.

\section{Martinez de la Puente}

Menos conocido y menos aún citado que las obras de López de Gómara y el P. Las Casas, dentro de la historiografía de Canarias, es el Epitome de la Crónica del Rey don Juan II de Castilla, de un tal Joseph Martínez de la Puente, publicado en 1678, en el que se dedica un capítulo entero (el cap. 23 del Libro I) al "Descubrimiento y conquista de las Islas de Canaria. Su número y cosas notables de ellas: y su origen, y costumbres de sus habitadores" ${ }^{39}$.

El Epitome de Martínez de la Peña sigue muy de cerca, en lo referido a Canarias, a la Conquista y Antigüedades de Núñez de la Peña, publicada dos años antes, y a quien cita repetidamente como fuente. Pero en lo referente al baile canario nos deja Martínez de la Puente una preciosa cita, mucho más elocuente que ninguna otra anterior de fuente historiográfica: "[Los naturales destas Islas] gustaban mucho (y aún hoy) de cierto bayle, o saltarelo muy gracioso, que llamamos en España canario, por aver venido su uso de aquellas Islas: y los instrumentos con que tocaban eran unas calabazas secas, con piedrecillas dentro, que servían de sonajas" ${ }^{40}$.

Parece claro que la cita del canario no la toma Martínez de la Puente de Núñez de la Peña ni de ningún otro historiador. Lo de "saltarelo gracioso" estaba antes en el Tesoro de Covarrubias (1611), lo mismo que la denominación de canario, "por haber venido de aquellas Islas" (dice Covarrubias). Lo que sí procede de Núñez de la Peña es lo de los instrumentos con que tocaban ${ }^{41}$ (añadiendo Martínez de la Puente "que servían de sonajas").

Lo que sí es aportación personal de Martínez de la Puente es que el nombre de canario se le da "en España" (en la Península, no en las Islas) y que todavía en la segunda mitad del s. XVII ("aun hoy" dice) se seguía bailando en las Islas, cosa que no sabemos de dónde puede tomar y que parece improbable.

39 Impreso en 1678 (sin lugar), a costa de Gabriel de León, Mercader de libros. Ahora puede verse en edición moderna, con estudio nuestro y de M. Loвo CabrrRa, en in capítulo desconocido de la historiografía de Canarias: El "Epítome" de la Crónica de Juan II, de J. Martínez de la Puente (1678), $X$ Coloquio de Historia Canario-Americana (Las Palmas de Gran Canaria: Casa de Colón, en prensa).

40 Ibid., p. 48.

${ }^{41}$.Los instrumentos con que tocaban - dice Núñez de la Peña- eran calabazas secas con piedrecillas dentro (Conquista y Antigüedades, p. 32). Noticia que, a su vez, Núñez de la Peña toma de Gómez Escudero: -Después de los vailes, onde hacían zonzonetes con piedresuelas i tiestos de varro (cf. F. Morales Padrón, Canarias. Crónicas de su Conquista). p. 435. 
Pero la cita de Martínez de la Puente tiene un interés bibliográfico añadido, que conviene comentar, deshaciendo una madeja harto enmarañada. El primer conocimiento del texto de Martínez de la Puente nos lo proporcionó el Diccionario de Autoridades, quien lo toma como aautoridad" para la documentación de canario en su acepción de 'baile'. Pero en la entrada lexicográfica correspondiente del Aut. se cita: «PUENT. Epitom. de don Juan el II, lib. I, cap. 23", abreviatura que no aparece en la Introducción que nuestro primer diccionario académico dedica a relacionar las distintas fuentes de sus ejemplos, y que ofrece alfabéticamente por períodos históricos y por géneros literarios. En esta relación aparecen dos PUENT. El primero se corresponde con Fr. Juan de la Puente (s. XVII), autor de una Conveniencia de las dos monarquías, y el segundo con el P. Luis de la Puente (asceta jesuita de Valladolid que vivió entre 1554 y 1624), al que no se le atribuye allí obra alguna. ¿A cuál de los dos PUENT. de la Introducción corresponde la cita de canario? Ningún PUENTE aparece como autor de ningún Epítome en ninguno de los Catálogos o Diccionarios bibliográficos disponibles para el investigador.

Desconocer al autor conlleva la imposibilidad de fijar un criterio histórico consecuente en relación con la materia de que se trata. Concretamente: siendo la cita de PUENT. la "autoridad" que el Aut. toma para registrar lexicográficamente la acepción de 'baile' de canario, ¿qué influencias pudo tener esa cita en la valoración histórica, historiográfica e incluso literaria posterior? Ya sabemos el poder de "norma" que tiene el Diccionario académico. Más concretamente: sin saber la fecha del Epítome y quién fuera su autor, ¿quién tomó la definición de canario 'baile' de quién? ¿Covarrubias de PUENT. O PUENT. de Covarrubias?

Porque sin saber quién fuera ese PUENT., el máximo historiador de Canarias, Viera y Clavijo, aceptó su testimonio incluyendo literalmente el texto del Aut. en su Historia de Canarias (libro I, cap. 14a), aunque Viera aquí silenciara la fuente de nuestro primer diccionario académico ${ }^{42}$.

Pues esa errata del $A u t$. - pues errata fue, sin duda ${ }^{43}$ - sólo la pudo subsanar el primer Diccionario bistórico de la lengua española ${ }^{44}$, quien al revisar todas las fichas lexicográficas existentes en la Academia corrigió

"2 Parece que el ocultamiento de fuentes o las citas confusas e incompletas sea un vicio hecho ya común entre los que se han ocupado del baile canario. Tradición tienen, teniendo tan buen maestro.

" De erratas de este tipo - y aún mayores-, que desconciertan y confunden al investigador y mucho más al simple usuario del Diccionario, está plagado nuestro primer diccionario oficial, pero aun con eso nuestro mejor diccionario.

44 Lo llamamos primero pues, como se sabe, la primera tentativa - a causa de la Guerra Civil - no pasó del tomo II, publicado en 1936, y sólo llegó a una parte de la letra C, para nosotros afortunadamente, pues incluyó canario (cf. M. SECO, "Medio siglo de lexicografía española (1930-1980),, Estudios de lexicografía española, Madrid, Paraninfo, 1989, pp. 194-220). 
al Aut. atribuyendo correctamente el texto del baile canario a [José] Martínez de la Puente, autor, éste sí, de un Epitome de la Crónica del rey don Juan el segundo de Castilla, publicado en 1678, y por lo tanto anterior y fuente del $A u t$.

\section{Glass y Viera (siglo xVIII)}

Otros dos testimonios importantes tenemos de la historiografía canaria del siglo XviII. El primero es de George Glass, un marino y comerciante inglés que recorrió las Islas y escribió en 1764 una interesantísima Descripción de las Islas Canarias ${ }^{45}$. En ella, al describir las fiestas populares de los pueblos del Archipiélago, dice: "Se bailan aquí muchos tipos de danzas, en particular zarabandas y folías, que son bailes lentos [...]. Las danzas rápidas son el canario, el fandango y el zapateo: la primera, era la danza de los antiguos canarios ${ }^{46}$.

Dos cosas interesa destacar de este texto del viajero inglés: que el canario es danza rápida y que, aunque se especifica su origen antiguo, pervive entre los bailes y danzas populares de los pueblos canarios a mitad del siglo XVIII.

El segundo testimonio del siglo XVIII se debe al gran historiador y enciclopedista canario José de Viera y Clavijo. Tan amplio es que ocupa un apartado entero, con su propio título: "El baile canariom, dentro del cap. 14 del libro I de su Historia de Canarias $^{47}$. El texto es heterogéneo y complejo. En él se habla, en efecto, del baile canario, aportando para el caso testimonios anteriores, como son el del Cronista de Indias Francisco López de Gómara (Viera cita "Francisco de Gómara") y el del historiador Fr. Juan Martínez de la Puente (Viera cita, equivocadamente por seguir al $A u t$., como dijimos, "Fray Juan de la Puente"), y se extiende después en otras dos consideraciones no propias del baile canario, como son los instrumentos que los guanches utilizaban en sus bailes y en la descripción de "otra especie de contradanza", propia de los naturales del Hierro, "cuya figura consistía - dice Viera - en tomarles las manos y marchar ambas líneas una hacia adelante y otra hacia atrás, dando furiosos saltos, todos juntos y paralelos" ${ }^{48}$.

Dos consideraciones, a su vez, le merece a Viera el baile canario: la primera (tomada del cronista Gómara), en la que ensalza y reconoce la

t5 Ed. de C. Aznar dF Acevedo (Santa Cruz de Tenerife: Instituto de Estudios Canarios, 1982).

40 Ibid., p. 127.

4- Op. cit., p. 157.

${ }^{48}$ Ver nuestra nota anterior 2, p. 4. 
fama alcanzada por el canario: “¿En qué parte del mundo - dice Vierano es celebrado el baile canario por su tono vivo, alegre y lleno de expresión?n; y la segunda en la que se describe su música (ésta tomada -aunque Viera lo silencie- de la definición del $A u t$.): "Este es un tañido músico - dice Viera- de cuatro compases qưe se danza haciendo el son con los pies, con violentos y cortos movimientos".

En resumen: el recurso de Viera de ampararse en testimonios y descripciones ajenos ${ }^{49}$, ad pedem literae, unas veces citando la fuente (Gómara), otras sin citarla (el Aut.) y otras citando mal (Juan de la Puente), parece indicar que, en este punto, el Arcediano de Fuerteventura no pudo constatar por sí mismo, ni por referencias cercanas a su tiempo, la pervivencia del canario en Canarias en esa segunda mitad del s. XVIII en que escribe su Historia, lo que parece más convincente que lo escrito por G. Glass ${ }^{50}$.

\section{Berthelot}

Y después de Viera y Clavijo, un último testimonio importante de mitad del s. XIX, por obra de otro viajero extranjero a las Islas, aunque éste se afincara hasta su muerte en Santa Cruz de Tenerife, el del naturalista francés Sabino Berthelot, quien en su Etnografía y Anales de la Conquista de las Islas Canarias (1842) ${ }^{51}$ aporta nuevos datos y una nueva visión del canario, apoyándose para ello en los testimonios de Gómara y de Viera. Consideración original de Berthelot es la de que el nombre del baile nació en España (y vino a las Islas), y de que el baile nació en las Islas y fue llevado a España por los esclavos aborígenes (un viaje cruzado de lengua y realidad). Dice el sabio francés: «El baile era también uno de los ejercicios favoritos de estos insulares y el que se conoce en España con el nombre de baile canario, fue introducido en Andalucía por los cautivos que llevaron a Sevilla" 52 .

Y añade además una interpretación inédita en la historiografía anterior: «Probablemente fue este mismo baile el que fijó la atención de los

\footnotetext{
". Testimonios y descripciones de autores, curiosamente en este caso, no canarios.

5. Incluso en contra de la opinión de $\mathrm{M}$. Menéndez Pelayo, quien al tratar sobre el canario que Lope de Vega introduce en su obra Los guanches de Tenerife, cita al edocto arcediano de Fuerteventura", quien al parecer - dice Menéndez Pelayo-, alcanzó todavía este baile, puesto que pondera su tono vivo, alegre y lleno de expresión- (M. Mfnéndez Pelayo, Estudios sobre el teatro de Lope de Vega, ed. de A. Bonilla y San Martín. Madrid, 1925, vol. V, p. 318). La valoración del baile por parte de Viera, en nuestra opinión. es más consecuencia de lecturas que de impresiones visuales directas.
}

" (Santa Cruz de Tenerife: Ed. Goya, 1978).

5 Ibid. p. 103. 
exploradores de Lisboa de 1341. Su canto es muy dulce -escribían al hablar de los habitantes de Canarias-, bailaban casi a la moda francesa" "33.

Se refiere aquí Berthelot a la expedición que, capitaneada por Angiolino del Tegghia, armó en 1341 el rey Alfonso IV de Portugal con la intención de conquistar unas islas todavía más míticas que reales. La expedición no logró su propósito último, pero hizo exploraciones en varias de las islas y tomó de ellas mercancías y esclavos, y con la noticia de su descubrimiento se pobló Europa de un afán de conquista que ya no se agotaría hasta lograrlo definitivamente los españoles en tiempos de los Reyes Católicos. El relato de aquella expedición se descubrió muy tardíamente, en un manuscrito de Boccaccio. Y ese relato es al que se refiere Berthelot cuando habla de los exploradores de Lisboan. No se dice en el relato de la expedición portuguesa-florentina que el baile conocido por ellos fuera el que después se bautizó con el nombre de canario, pero nada impide decir que no lo fuera, y que, entonces, por vía de esos esclavos que se llevaron, el baile se diera a conocer en España y en Europa a mitad del s. XIV, dos siglos antes de que aparezca la palabra que le dio nombre. Así dice el manuscrito de Boccaccio: "[Los canarios] cantan dulcemente, danzan como los franceses y son risueños, alegres y más civilizados que muchos españoles" ${ }^{54}$.

Y respecto a los testimonios de Gómara y de Viera los adapta Berthelot a su redacción particular, en versión libre, por mucho que las citas aparezcan como copiadas literalmente (entre comillas). Había dicho el cronista Gómara: "El canario, baile gentil y artificioso", y ahora dice Berthelot que el cronista dijo: "El baile canario, tan variado y lindo". Había dicho Viera y Clavijo: "EEn qué parte del mundo no es celebrado el baile canario por su tono vivo, alegre y lleno de expresión? [...] Este es un tañido músico de cuatro compases que se danza haciendo el son con los pies, con violentos y cortos movimientos", y ahora dice Berthelot que el arcediano dijo: "El baile canario, ejecutado dos a dos o varios juntos, consistía en una gran ligereza de pies, acompañado de movimientos muy expresivos del cuerpo".

En fin, ya se ve que Berthelot interpretó muy libremente lo que Gómara y Viera dijeron. Más parece que el francés utilizara aquí otros testimonios con atribución errónea o que su cita sea una reelaboración personal a la vista no sólo de los textos de Gómara y de Viera sino de la ya larga tradición descriptiva sobre el baile canario.

53 Ibidem.

54 Cit. por A. Millares Torres, Historia General de las Islas Canarias (Las Palmas de Gran Canaria: Edirca), vol. I, p. 159. 


\section{FUENTES LITERARIAS}

\section{Sánchez de Badajoz}

El texto literario de canario 'baile' más ţemprano registrado hasta ahora es uno de Diego Sánchez de Badajoz, cuya producción dramática se sitúa entre 1525 y $1547^{55}$, aunque fue publicada unos años más tarde en Sevilla, en 1554, bajo el título genérico de Recopilación en metro. En el texto, puesto en boca de uno de sus pastores, se cita el canario entre otros bailes populares de la época:

\section{Mas saber bailar ahítas, villano, canario y quiebra ${ }^{50}$.}

Frente a este solitario texto del XVI, son numerosos los del xvil que hablan ya de la fama del canario y de su plena integración entre los bailes y danzas populares de la España de entonces. Por citar una sola fuente, abundantísima en testimonios de la época, sea la de M. Frenk en su extraordinario Corpus de la antigua lírica popular bispánica (ss. XV a $X V I)^{57}$, en el que en el capítulo correspondiente a la música y al baile documenta el canario en los autores más sobresalientes de nuestro Siglo de Oro: Cervantes, Lope, Quevedo, Calderón, Valdivielso, Simón Aguado, Agustín de Rojas y Sebastián de Villaviciosa, además de otros textos anónimos populares. De entre los citados por M. Frenk, y algunos otros no contenidos allí, comentaremos los más interesantes.

\section{Viana}

Antonio de Viana, el poeta lagunero que cantó en verso épico las Antigüedades de las Islas Afortunadas y la Conquista de Tenerife (1604), no podía dejar de citar el canario entre las recreaciones preferidas por los aborígenes. Y así lo hace, efectivamente, en un ambiente muy bucólico del canto IV, aquí sólo como "Son", como música:

$$
\begin{aligned}
& \text { Resuena el tono acorde de la música, } \\
& \text { los instrumentos son dos calabazas } \\
& \text { secas y algunas piedrecitas dentro, } \\
& \text { con que tocaban dulce son canario... }{ }^{58} \text {. }
\end{aligned}
$$

"5 Cf. la introducción de J. M. Difz Borque a su ed. de D. Sanchez de. Badajoz, Farsas (Madrid: Cátedra, 1978), especialmente pp. 25-31.

5. Recopilación en metro, ed. Lib. de Ant., t. I, p. 210 (tomado del Dicc. bistórico).

"' (Madrid, Castalia, 1987), cap. VII.

$5 *$ Ed. M. R. Alonso (Biblioteca Básica Canaria, Viceconsejería de Cultura del Gobiemo de Canaria, 1991, canto IV, vv. 468-71). 
Es sabido que la fuente histórica principal de Viana es el P. Espinosa, pero también es conocido el tono idealizado con que Viana pinta los ambientes y las costumbres de los canarios aborígenes. Así, en ese mismo contexto, empezada la música, empieza también el baile -el canario-, que no ha de ser sino de simple honestidad y llano término::

Comiénzanse ante el rey bailes solemnes, no la descomulgada zarabanda, chacona, gatatumba, o los meneos de varias descompuestas cerimonias; antes con el recato y cortesía que puede permitirse sin agravios de simple honestidad y llano término, hacían saltos, vueltas y mudanzas.

(Canto IV, vv. 485-92)

\title{
Valdivielso
}

El siguiente texto pertenece al Romancero espiritual de José de Valdivielso (1612) ${ }^{59}$, al precioso villancico que empieza con su estribillo:

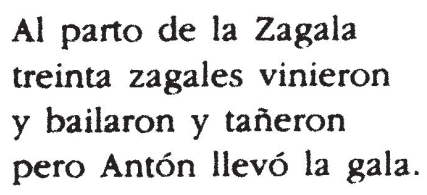

Como el ambiente que en él se refleja es rústico y pastoril, rústicos y populares resultan ser los bailes y músicas que en él se citan (el dongolondrón, la cebolla con el pan, el rabanico con queso, el guárdame las vacas, el déjame Periquito Sancha, además de la gala de Medina), entre los cuales está el canario:

\author{
Danzó Esparto, \\ como mona, \\ canaria bona; \\ Pablo Ensancha \\ déjame Periquito Sancha; \\ y Marina \\ a la gala de Medina ${ }^{\text {ot? }}$.
}

\footnotetext{
59 Ed. de Ribadeneyra (Madrid, B.A.E., XXXV, 1950), p. 193.

6o La fórmula canaria bona. (y sus variantes canario y bona-, canario a bona", canaria lira. y otras similares) se fijó como verso de estribillo propio del baile canario. Cf. M. Frenk, Corpus, núms. 1521A, 1521B, 1521C y 1522.
} 


\section{Cervantes}

Aparece después tres veces en un mismo texto de Cervantes, como remate de su Entremés de El Rufián viudo $(1615)^{61}$, en situación y contextos tales que hablan ya muy claramente de la popularización (incluso vulgarización) del baile canario, al lado de la gallarda, la zarabanda o el villano. El bailarín del canario cervantino será Esparramán, un personaje típicamente quevedesco que encarna el sentimiento antiheroico que va dominándolo todo en los principios del s. XVII. "LA enorme popularidad de la járara quevedesca -dice Menéndez Pidal- llega a su cumbre hacia $1603^{62}$. Cervantes, en su entremés de El rufián viudo - sigue diciendo Menéndez Pidal - hace que Escarramán pregunte cómo anda su fama, y le responden que su nombre circula por plazas y por calles, que lo bailan muchachos en teatros y en las casas, y que las fregonas lo alaban en el río y lo cantan los mozos de caballos; es decir, anda en las coplas de los más bajos y en los gustos de todos ${ }^{63}$. $\mathrm{Y}$ todos los personajes de El rufián viudo cantan en alabanza del antihéroe:

Ya salió de las gaurapas

el valiente Escarramán, para asombro de la gura y para bien de su mal.

Es en este contexto cuando el Escarramán baila primero la gallarda, mientras los demás cantan:

Muden el baile a su gusto,
que yo le sabré tocar:
el canario, o las gambetas,
o al villano se lo dan,
zarabanda, o zambapalo,
el Pésame dello y más,
El rey don Alonso el Bueno.
Gloria de la antigüedad.

A lo que Escarramán contesta:

El canario, si le tocan, a solas quiero bailar.

(1) M. de Cerrantrs, El juez de los divorios y otros entremeses (Madrid, 1986).

62 R. Mfnendez Pidal, Romancero hispánico (Madrid: Espasa-Calpe, 1968, 2.^ ed.), p. 201.

in Ibidem. 
Propuesta que aceptan encantados los músicos:

Tocaréle yo de plata;

tú de oro le bailarás.

Y, efectivamente -concluye en anotación Cervantes-, "Toca el canario, y baila solo el Escarramán" ${ }^{64}$.

\title{
Quevedo
}

Lo cita también Quevedo, en contexto vulgarizador, recordando quizá aquellas maneras primitivas del zapateado brusco y primitivo que dicen caracterizaba el baile de los aborígenes canarios:

$$
\begin{aligned}
& \text { Con un rabel un barbero } \\
& \text { con una duela danzaba, } \\
& \text { y, acoceando el canario, } \\
& \text { hacía hablar un sala }{ }^{65} \text {. }
\end{aligned}
$$

Lope

Y lo hallamos documentado, por último, en tres de las obras dramáticas de Lope de Vega, las dos primeras de temática canaria. En una de ellas, en San Diego de Alcalá, glosando la vida del santo franciscano de Fuerteventura, pone un estribillo del canario en boca de unos aborígenes mientras lo bailan ${ }^{66}$ :

\author{
Canaria lira, \\ lilirum fa; \\ que todo lo vence \\ amar y callar. \\ En la Gran Canaria \\ isla de este mar,
}

\footnotetext{
${ }^{04}$ El querer bailar a solas Escarramán el canario es interpretado por $M$. Querol como deseo de lucirse ante la concurrencia: tales dificultades tenía el baile y tales habilidades requería ("tú de oro le bailarás*). Cf. M. Quifror, La música en las obras de Cervantes (Barcelona: CSIC, 1948), pp. 99-101.

is Ficha del Seminario de Lexicografía de la RAE, Obras completas de Quevedo, ed. crít. de L. Astrana Marín (Madrid, 1932), t. Il, p. 371.

to Ficha del Seminario de Lexicografía de la RAE; cit. por P. Henriqtifz URena, Estudios de versificación (1961). Cit. también por M. Frenk, Corpus, núm. 1522; y por E. Alonso, Tierra canaria, fasc. 1.
} 
que los españoles

quieren conquistar

para el rey Enrique

que en Castilla está,

nacen cumbres fuertes

que la guardarán.

Canaria lira,

lilirum fa;

que todo lo vence

amar y callar ${ }^{67}$.

El segundo texto del Fénix procede de Los guanches de Tenerife $(1618)^{68}$ : en la mitad del $2 .^{\circ}$ acto, el valiente Bencomo consuela a su amada Dácil y ordena el canto y el baile:

No entristezcas así.

Cantad, bailad, alegrad

de mi alma la mitad.

Y empieza a bailar "el canario" - dice Lope- mientras los músicos cantan en estrofas hexasilábicas la gran valentía y fuerza de los guanches, que harán temblar y huir a los españoles, con el siguiente estribillo:

$$
\begin{aligned}
& \text { Españoles bríos, } \\
& \text { mirad y matar; } \\
& \text { volveréis vencidos: } \\
& \text { fan, falalán. }
\end{aligned}
$$

Y en la tercera obra, ésta de temática no canaria, La villana de Jetafe $(1621)^{69}$ pone al canario al lado de otros bailes populares, como las folías, el villano, las vacas y Conde $\operatorname{Claros}^{70}$.

\footnotetext{
") Una variante de este estribillo la vuelve a utilizar Lope en su auto La Araucana, cantando y bailando: ‘Canaria bona / lirunfá, / que Rengo es vencido / por Caupolicán. (cit. por M. FrFnk, Corpus, núm. 1522).

(18 Esta obra de Lope está inspirada en el poema heroico del poeta tinerfeño Antonio de Viana, Antigüedades de las Islas Canarias (Sevilla, 1604), a quien el Fénix alaba en un soneto.

(a) Cit. por Aurelio CApmany, "El baile y la danza., Folklore y Costumbres de España, director, F. Carreras y Candi (Barcelona, 1934), vol. II, p. 196.

7) El de slas vacas. referido, sin duda, a la conocidísima pieza -Guárdame las vacas-, que tantas glosas y variaciones musicales alcanzó en los ss. xvi y xvi; y el -Conde Claros- referido al baile romancesco en el que lo que se canta es el romance del mismo título, el más popular de entonces.
} 


\section{FUENTES TÉCNICAS}

El paso del baile canario de España a Europa debió ser muy temprano, posiblemente inmediato a su llegada a la Península. De tal manera que las primeras documentaciones sobre el canario son casi contemporáneas a las españolas. Y eso porque -como dice Menéndez Pelayo- eninguna de estas artes [la danza, la pantomima, la declamación] tiene en España bibliografía importante ni copiosa, tal por lo menos que pueda competir con la italiana o la francesa. No hay entre nosotros tratadista alguno de baile que se remonte a la muy respetable antigüedad [del $s . \mathrm{xv}$ ]. ${ }^{71}$. Y por lo que al canario respecta, los tres primeros libros de danza en que aparece documentado son extranjeros, bien es verdad que, como dice Menéndez Pelayo, estos libros son -comprensivos solamente de las danzas aristocráticas y cortesanas y en ningún modo de las populares. ${ }^{72}$.

El primero de ellos, de 1588, es de un canónigo francés llamado Johan Taburot, de seudónimo Thoinot-Arbeau, autor de un libro titulado Orquesographie, en el que se describen las melodías, ritmos y bailes más famosos de los salones europeos de la época. Entre ellos el canario, al que describe con cierta minuciosidad, resaltando el carácter brioso de sus pasos y saltos, "pareciéndose en gran manera a la danza de los salvajes" ${ }^{73}$.

El segundo es del italiano Fabricio Caroso da Sermonetta, quien en su Ballarino (finales del s. XVI) incluye como danzas típicamene españolas: la pavana, la españoleta, la gallarda y el canario ${ }^{74}$.

$\mathrm{Y}$ el tercero es del también italiano César Negri, cuya obra Nuove Inventioni di Balli (Milán, 1604), que alcanzó singular boga en España por estar dedicada a nuestro rey Felipe III, cita como bailes españoles: el villano, la barrera, la alemana, la pavana y el canario ${ }^{75}$.

7 M. Menéndez Pelayo, Historia de las ideas estéticas en España (Madrid: CSIC, 1940), t. III, p. 653. Debo el conocimiento del Apéndice del sabio santanderino dedicado a las *Artes Secundarias: danzas y pantomimas, declamaciones, etc., etc.", final de su libro, al notable bibliófilo don José León, bibliotecario de El Museo Canario de Las Palmas de Gran Canaria.

7 Ibid., p. 654.

3 La noticia de este tratado de Thoinot-Arbeau la recoge L. Siemfns en su artículo tLa música aborigen. (cit., pp. 358 y 359), aportando una serie gráfica de seis figuras, cada una de las cuales muestra un paso de baile del canario. También lo cita E. Alonso en sus Estudios de folklore canario (cit., p. 94), transcribiendo la descripción de Thoinot Arbeau: :Un joven toma a una dama y bailando con ella al compás de una melodía conveniente, la conduce al extremo del salón. Esto hecho, vuelve al sitio desde donde empezó, mirando mientras tanto a la dama. Luego se dirige nuevamente hacia ella, efectuando ciertos pasajes, y una vez realizado esto, se vuelve como antes a. su lugar. Entonces la dama viene y efectúa lo mismo frente a él, volviendo después al lugar donde estaba y ambos continúan estas idas y venidas tantas veces como la diversidad de los pasajes se lo permite. $Y$ advertí que estos pasajes son animados, aunque estraños y fantásticos, pareciéndose en gran manera a la danza de los salvajes-.

7. Cit. por M. Menéndez Pelayo, Historia de las ideas estéticas, p. 654.

Ibidem. 
Ya dentro de España, el principal tratado de baile ${ }^{76}$ de los siglos de oro es el titulado Discursos sobre el arte del danzado, de Juan de Esquivel Navarro (1642). En él empiezan a aparecer por primera vez -como advierte Menéndez Pelayo-, mezclados con las danzas cortesanas, los más famosos bailes populares; así el canario (baile muy "usualn, según lo califica Esquivel), el basto, la tárrega y la jácara, junto (o frente) a otros "elegantes", como la españoleta ${ }^{77}$.

$\mathrm{Y}$, por último, a finales del s. XviII, lo volvemos a hallar documentado en otro libro titulado Elementos de la ciencia contradanzaria del escribano vizcaíno Zamácola, oculto bajo el seudónimo de Don Preciso (1796) ${ }^{78}$ : *Habiéndose admitido después el trage también nacional, que hoy llamamos de Majo, siguió con él baylando el entramuro, el combé, la pelicana, el canario, el cerengue, la tirana.... ${ }^{79}$.

El carácter de baile alegre, rápido y muy movido del canario se convirtió en proverbial. No hay cita ni descripción, ni simple referencia, que no lo contenga. Es muy ilustrativo a este respecto el artículo lexicográfico que le dedica el Oxford Dictionary, que recoge múltiples citas de autores ingleses, desde finales del siglo XVI hasta el XIX. El primero de los citados, Nashe (en 1592), dice: "Tan animado como si estuviera bailando canario". El segundo, Saks (en 1601): "Una medicina capaz de resucitar a un muerto y ponerte a bailar canarion. Etc. De la misma manera ha pasado a los diccionarios de música; por ejemplo, el de Michel Brenet ${ }^{80}$, quien, incluso, documenta una danza llamada canaria, "puesta de moda [en Francia] -dice- durante el reinado de Carlos IX (1560-1574) que tomó su nombre de una mascarada en que los danzarines iban vestidos de salvajes de Canarias y ejecutaban pasos extravagantes que tenían fuerte sabor salvaje. ${ }^{81}$.

A más abundancia, aún sin citar la fuente de donde lo toma, leemos en el escritor canario Leoncio Rodríguez lo siguiente:

Nuestro baile, "menudico y agudo», llegó a ser una de las favoritas diversiones de la Corte de Francia y más tarde en los góticos castillos de la nobleza alemana.

Un autor francés refiere que en tiempos de Luis XIV se puso de moda en su Corte, y el propio rey se dignó bailarlo vestido de guanche, con las piernas desnudas, el cuerpo cubierto de pieles y el bastón de mando en la mano.

\footnotetext{
"Así lo califica P. Henriquez Ureña, Estudios de versificación (ficha del Seminario de Lexicografía de la RAE).

"Discursos sobre el arte del danzado, cit. en pp. 21, 26b, 30b, 31 y 41.

7* Cf. M. Mrnéndfz Pflayo, Historia de las ideas estéticas, p. 657.

To Ficha del Seminario de Lexicografía de la RAE.

*1) Diccionario de la müsica bistórico y técnico, (Barcelona: Joaquín Gig ed., 1946). Tomo la cita de M. R. Alonso, -Las danzas y canciones populares de Canarias-, p. 83, nota 2 y pp. 87-88.
}

81 Cit. M. R. Alonso, ibid., p. 88. 


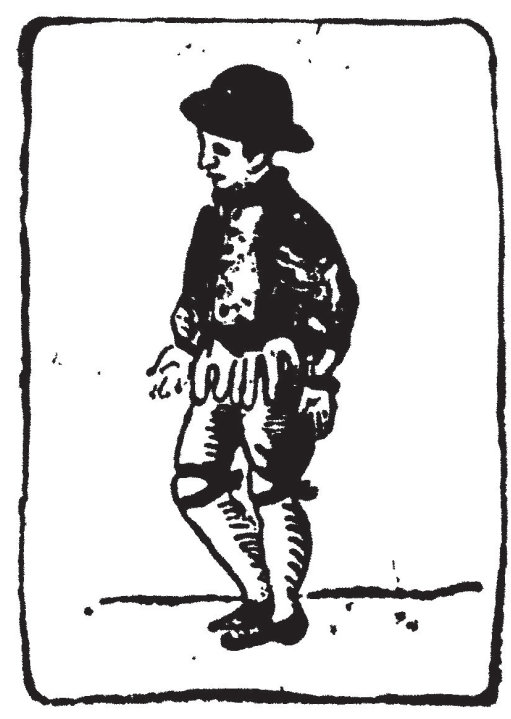

Marque el pie derecho

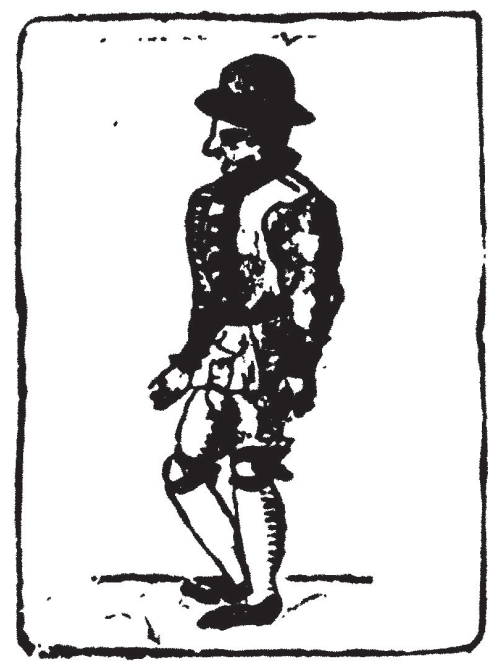

Marque el talón derecho

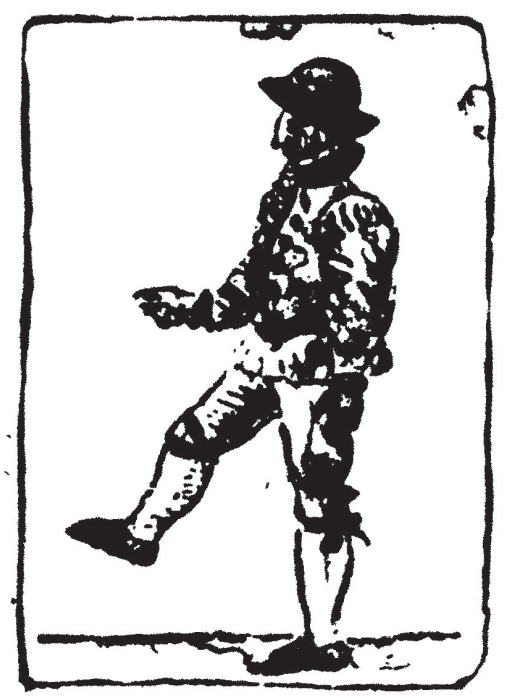

Levante al aire el pie derecho

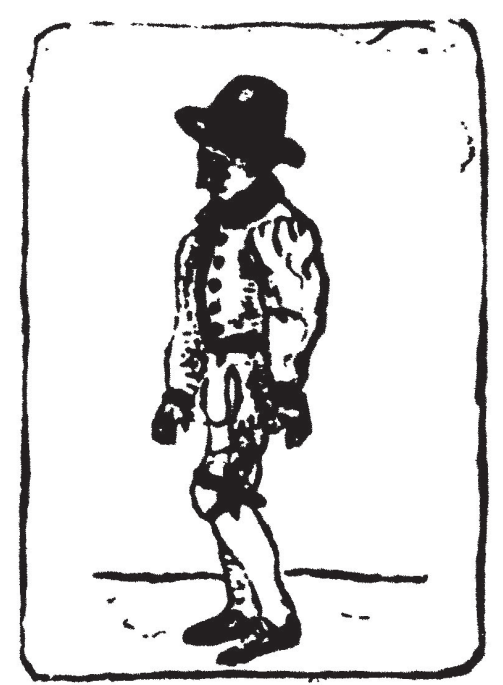

Marque el pie izquierdo

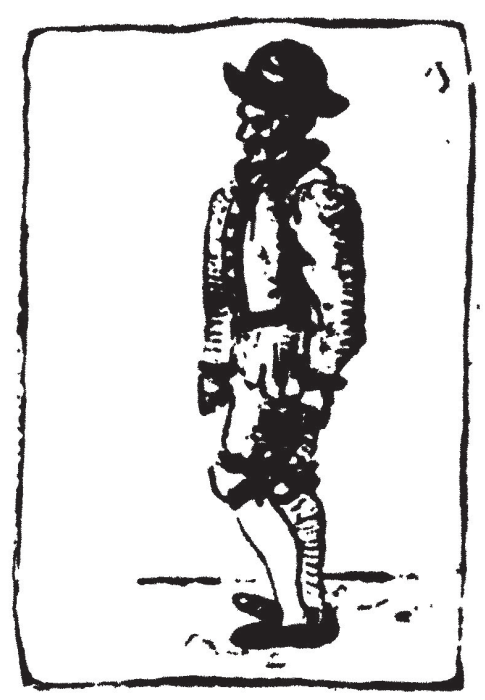

Marque el talón izquierdo

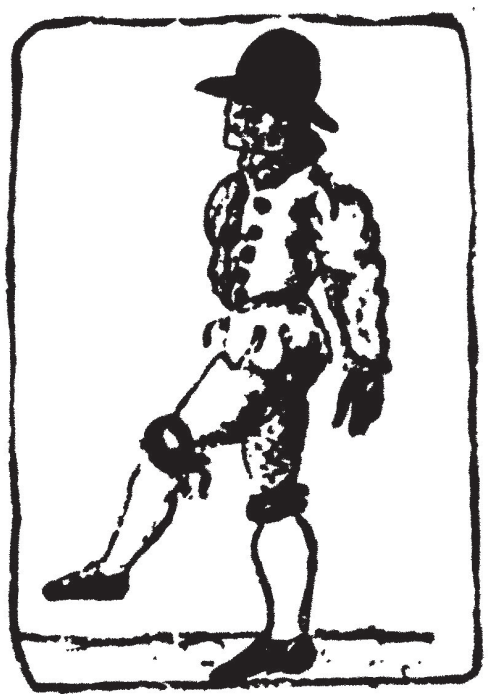

Levante al aire el pie izquierdo 
El rey y su pareja, en medio de una cuadrilla de cortesanos, bailaban nuestra danza; las parejas se acercaban, apartábanse después con signos de desdén o simulando desprecio, y, por último, la amante esquiva se rendía en medio del regocijo general y la satisfacción del rey ${ }^{82}$.

\section{FUENTES LEXICOGRÁFICAS}

\section{Covarrubias}

La historia de la lexicografía española se inicia propiamente a finales del s. XV con el Dictionarium latino-bispánicum (1492) de Antonio de Nebrija, aunque dos años antes se había publicado el Vocabulario Universal de A. de Palencia ${ }^{83}$. Pero ni en el de Nebrija ni en el de Palencia (muy inferior al de aquél) se contiene todavía la palabra canario con su acepción de 'baile' ${ }^{84}$. Hay que esperar más de un siglo, hasta 1611, para hallarla registrada en el primer diccionario realmente importante del español, el Tesoro de la lengua castellana o española de Sebastián de Covarrubias. De las tres acepciones que Covarrubias atribuye a canario, la segunda, referida al baile, dice: "Género de saltarelo gracioso que se truxo a España de aquellas partes [de las Islas Canarias] ${ }^{85}$.

\section{El "Autoridades"}

Y del "Saltarelo" de Covarrubias tenemos que volver a dar nosotros otro gran salto de más de un siglo para hallar el canario en otro registro lexicográfico, éste ya definitivo, porque con él quedará fijada la definición académica de canario 'baile'. Nos referimos, claro está, al Diccionario de Autoridades (1726-1739) de la recién creada Real Academia de la Lengua. Así lo define el Aut.: "Tañido músico de cuatro compases que se danza haciendo el son con los pies, con violentos y cortos movimientos". Y toma después el testimonio de Covarrubias para

i2 Leoncio RonRicilizz, "El alma popular", Ensayistas canarios, ed. Alfonso Armas Ayala (Biblioteca Básica Canaria, núm. 17, Gobierno de Canarias, Viceconsejería de Cultura y Deportes, 1990), p. 94.

*A Autor a quien, por cierto, la historiografía de Canarias le debe un capítulo de sus Décadas dedicado a la "Conquista de Gran Canaria. Cf. F. Morales Padron, Canarias. Crónicas de su conquista, pp. 471-496.

*4 En ellos sólo se registra el nombre de Islas Canarias y alguno de los otros que se le dieron a las islas en al antigüedad, como Islas de la Fortuna, Fortunadas o Bienaventuradas.

85 Ya dijimos antes que esta fórmula de Covarrubias sería recogida después por Martínez de la Puente en su Epítome como saltarelo muy gracioso. 
decir que se llama así "por haber traído a España esta danza los naturales de Canarias:. Y pone, por último, la cita del Epitome de José Martínez de la Puente (citado sólo PUENT.) como *autoridad. literaria para su registro ${ }^{86}$.

\section{El DRAE}

Desde la definición del $A u t$. hasta la que figura en la última edición del DRAE, pasando por las 20 ediciones intermedias, que todas deben entenderse como continuadoras de aquél, hay unas cuantas modificaciones y una serie de vaivenes en la redacción del artículo lexicográfico que ponen de manifiesto bien claramente la historia "poco semántica" del Diccionario académico. Pues lo que se ha modificado no es el objeto a definir (que en ese caso estaría justificado), sino la propia definición, sin que además hubiera motivo para ello ${ }^{87}$.

En el DRAE-92 se diferencian dos acepciones de canario 'baile': la primera de ellas se refiere al propio baile: "baile antiguo procedente de las Islas Canarias que se ejecuta en compás ternario y con gracioso zapateo" y la segunda a su música: "tañido de este baile».

Las diferencias entre el $A u t$. y el DRAE-92 son evidentes, pero en medio queda una historia lexicográfica quebrada, que hemos estudiado con detenimiento en otro lugar ${ }^{88}$, y que aquí no haremos sino esquematizarla:

a) En primer lugar, hay una radical inversión de referencias: de la definición del Aut., que recae principalmente sobre la música y secundariamente sobre el baile ('música que se danza'), se pasa al DRAE-92 a considerar primero el baile y secundariamente la música, expresadas ambas como acepciones (¿significados?) diferenciadas.

b) Esta diferenciación de acepciones - baile' por una parte y 'música' por otra- empieza a practicarse a partir de la XIII ed. del DRAE (1899), si bien en la IX ed. (1843) se modificó ligeramente la redacción del artículo lexicográfico (invariable desde el $A u t$.) poniendo bien a las claras las dos realidades que quieren distinguir, aunque todavía en una sola acepción: "Tañido músico de cuatro compases, y baile correspondiente, acompanando al son con violentos y cortos movimientos".

86 Recordamos aquí la confusión provocada en este punto por el Aut. con su cita de PUENT. y la copia literal que de esa definición hace - sin citar la fuente-Viera y Clavijo.

8. Sobre esta cuestión, véase nuestro estudio .Variantes e invariantes de contenidom, cit. en la nota 21 anterior.

8 Ibidem. 
c) Respecto a la naturaleza rítmica de la música del canario, el Diccionario académico cambia inexplicablemente de redacción, sin que el baile hubiera cambiado en su ejecución (en realidad el canario había dejado de bailarse tiempo atrás): Desde el $A$ ut. hasta la XII ed. (1884) el canario se definía como un tañido "de cuatro compases", mientras que desde la ed. siguiente (1899) hasta la actualidad pasa a ser-dice la Academia - una música "que se ejecuta en compás ternario" ${ }^{89}$.

d) Por último, respecto a la forma de ejecución del canario, desde una primera redacción en la que se decía que era una danza "con violentos y cortos movimientos" marcados por los pies (que se mantiene invariable desde el Aut. hasta la ed. XII-1884), se pasa desde la ed. siguiente (1899) a decir que consiste en un "gracioso zapateo". Notable diferencia expresiva, sin duda.

En resumen: tres tipos de redacciones sobre la definición de canario 'baile' se suceden a lo largo de 266 años de lexicografía académica (381 años si en esa historia consideramos el Tesoro de Covarrubias):

1. $\quad$ Una primera que va desde el Aut. hasta la VIII ed. (1837) en la que se define como una única acepción de "Tañido músico de cuatro compases que se danza haciendo el son con los pies, con violentos y cortos movimientos".

2. ${ }^{2} \quad$ Una segunda, intermedia y transitoria, que se reproduce desde la ed. IX (1843) hasta la ed. XII (1884) en la que, aún en una sola acepción, empieza a diferenciarse ya netamente el baile, por una parte, y su música, por otra: "Tañido músico de cuatro compases, y su baile correspondiente, acompañando al son con violentos y cortos movimientos".

3. $\quad$ Y una tercera que se mantiene desde la ed. XIII (1899) hasta la actualidad (excepto, curiosamente, en las ed. XIV, 1914, y XV, 1925, en las que sin explicación alguna se vuelve a la definición anterior, es decir, a la iniciada en 1843), en la que las dos acepciones del baile y de la música se diferencian explícitamente dándoles dos entradas y cambiando incluso el orden de referencia que tuvo anteriormente: primero el de "baile antiguo procedente de las Islas Canarias que se ejecuta en compás ternario y con gracioso zapateo" y después el de "tañido de este baile.

8) Redacciones varias que, aunque desde un punto de vista musicológico no tienen necesariamente que ser contrapuestas, al hablante normal del español (que es el usuario ordinario del Diccionario) si se lo parece. 


\section{CONCLUSIONES}

1. Existió un baile entre los aborígenes de Canarias que antes incluso de su Conquista, en el siglo XIV, llegó a España por vía de los muchos esclavos que allí fueron llevados.

2. Al baile se le denominó canario, por su procedencia de las Islas Canarias.

3. El baile, que por su naturaleza era vivo y brioso, "de violentos y cortos movimientos", fue causa de admiración y tuvo aceptación inmediata en los ambientes cortesanos y galantes de España, y empezó a imitarse transformándose en danza "gentil y artificiosa" a la que siguió llamándose canario.

4. Con ese nuevo carácter se extendió también por las cortes y por los ambientes aristocráticos de Europa, entrando a formar parte de la nómina de danzas más representativas de la época (siglos XVI y XVII).

5. Pero a la vez que evolucionó hacia formas de danza galante, evolucionó también (o pervivió en sus formas más primitivas) hasta ser baile muy popular entre los ambientes más vulgares.

6. El carácter del canario como baile alegre, rápido y de movimientos violentos, "como de salvaje", se hizo proverbial en toda Europa. "Bailar canario" valía por 'moverse con extraordinaria agilidad y fuerza'. Y con razón puede decirse que el canario ha sido ala más importante aportación cultural a Europan de los aborígenes isleños ${ }^{\% 0}$.

7. La denominación de canario llegó también a Canarias, pero con referencia exclusiva al baile antiguo de los aborígenes. Sólo G. Glass, entre los muchos historiadores y viajeros de las Islas Canarias, asegura que seguía vigente entre los bailes populares de las Islas en la mitad del siglo XVIII.

8. El antiguo baile de los aborígenes canarios habrá podido pervivir en las Islas, bien que modificado por las formas cortesanas que adquirió en España y en Europa (el sirinoque de La Palma, según todos los indicios), bien que conservado en su naturaleza, o evolucionando naturalmente (el tajaraste de Tenerife y el baile del tambor de La Gomera, según algunos autores), pero el nombre del canario se perdió del todo. Hoy no hay en Canarias ninguna danza o baile al que se le llame canario $^{91}$.

90 L. Siemens, La música aborigen., p. 355

91 Cf., por ejemplo, M. Alvar, Atlas lingüüstico y etnográfico de las Islas Canarias (AlEICan) (Las Palmas de Gran Canaria: Cabildo Insular de Gran Canaria, 1975), t. II, lám. 756, mapa 703. 
9. Las caracterizaciones principales del canario, desde la perspectiva de la lengua, en las varias definiciones de los diccionarios o en las calificaciones que le dan los textos principales de los que nos hemos servido, ordenados cronológicamente, son los siguientes:

Crónica portuguesa (1451): Baile muy particular y digno de admiración.

Crónicas canarias (ss. XV-XVII): Zapateado lleno de mudanzas y cabriolas.

Gomara (1552): Baile gentil y artificioso.

MéNDEZ Nieto (1561): Baile muy canario.

TORRIANI (1592): Famoso baile.

EsPinOSA (1594): Baile de mucha ligereza y mudanzas.

Abréu Galindo (1602): Baile menudico y agudo.

Viana (1605): Dulce son canario, lleno de saltos, vueltas y mudanzas.

Thoinot-Arbeau (1588): Baile muy brioso, parecido a la danza de los salvajes.

CovarRubias (1611): Saltarelo gracioso.

NúNEZ DE LA PENA (1676): Lo bailaban con destreza y diversas mudanzas.

Martfnez de la Puente (1676): Saltarelo muy gracioso.

Autoridades (1726): Tañido de cuatro compases que se danza haciendo el son con los pies con violentos y cortos movimientos.

Glass (1765): Danza rápida.

VIERA (1772): Baile de tono vivo, alegre y lleno de expresión.

Berthelot (1842): Baile ejecutado con una gran ligereza de pies, acompañado de movimientos muy expresivos del cuerpo.

DRAE (1992): Baile antiguo procedente de las Islas Canarias que se ejecuta en compás ternario y un gracioso zapateo.

Principales fuentes de Canario 'BAile'

\section{Historiográficas}

Crónicas canarias (xV-XVII)

Gómara (1552)

Méndez Nieto (1561)

Torriani (1590)

Espinosa (1594)

Abréu (1602)

Núñez de la Peña (1676)

Martínez Puente (1678)

Glass (1764)
Viera (1772)

Berthelot (1842)

Literarias (ss. XVI-XVII)

Sánchez de Badajoz (1554)

Viana (1604)

Valdivielso (1612)

Cervantes (1615)

Lope (1618 y 1621) 
Quevedo (principios XviI)

\section{Técnicas}

Thoinot-Arbeau (1588)

Caroso (fines s. Xvi)

Negri (1604)

Esquivel (1642)

Don Preciso (1796)
Lexicográficas

Covarrubias (1611)

Autoridades (1726)

DRAE (21 ediciones)

Dicc. bistórico (1936)

Dicc. manual (1983)

DILE (1977)

DUE (1980)

VOX (1987)

MAXIMIANO TRAPERO

Universidad de las Palmas de Gran Canaria

El Diccionario académico define la palabra canario, en su $4 .^{2}$ acepción, como 'baile antiguo originario de las Islas Canarias', y en su 5." acepción como 'tañido correspondiente a ese baile'. Tiene razón la Academia de la Lengua Española al decir que es un baile antiguo, pues en la actualidad no queda ni en Canarias ni fuera de las Islas baile alguno que reciba ese nombre. $Y$ sin embargo en los siglos xvı y xvı fue un baile muy popular en España y en Europa. Aquí se documentan y estudian las principales citas del canario 'baile' en las fuentes historiográficas, literarias, técnicas y lexicográficas.

The Spanish Academy Dictionary defines canario (canary) in its fourth meaning as oold dance from the Canary Islands. and in the fifth meaning as ssound and music of that dance.. The Academy is right to say, that this dance is old since, nowadays there is no dance in the C.I. or outside the islands with the name of canario. However, during the 16 th. and 17 th. centuries it was a very popular dance in Spain and Europe. We try to gather material and do some research on the most important quotations of the canario dance among literary, musicology, historiography and lexicographical sources. 